\title{
History of Psoriasis
}

\author{
Ines Brajac and Franjo Gruber \\ Department of Dermatovenerology, University Hospital Centre Rijeka \\ Croatia \\ "It is not a disease on which to build a medical reputation" \\ E. Wilson
}

\section{Introduction}

Psoriasis is probably as old as mankind. Today, it is a well defined skin disease, in which genetic, environmental and immunologic factors participate in etiopathogenesis. However, despite its frequency, chronicity and visibility, it is quite hard to find a description of psoriasis in the works of the ancient physicians.

Dermatology developed slowly, first with appearance of the protodermatologists at the end of the 18th century, and continued with the arrival of the first dermatologists. From those times psoriasis became a distinct entity.

However, until the last century, the descriptions of disease considered «morbi in pulchredine», were rather vague, the denomination not standardized and the translation from one language to others discrepant. Different authors called the disease with various names, while diverse diseases had the same names. The confusion in terminology and description of psoriasis lasted for centuries.

\section{Psoriasis through history: Description and definition}

\subsection{Psoriasis in the old age}

The medicine developed in Mesopotamia, peopled by Sumers, Assirs, and Babylons. The oldest written witness regarding their medicine is clay tablets 3000-5000 year old (Radbill, 1975). Skin diseases have been known to Mesopotamian physicians, called asu, but was cured usually by seers and priests. Definitely there is not notice of psoriasis.

According to Herodotus in the pharaonic Egypt there were physicians for every organ. Numerous medicaments were used, along with magical ceremonies and enchantments (Herodotus, 1989). Hovewer, nothing relate to psoriasis in their medical papyruses. In the largest writing, the Ebers papyrus written about the 15th century BC, found in 1873 in Luxor, numerous skin diseases were described (paragraph 90-95 and 104-118). The term šuf. $\mathrm{t}$ for scale was find, but it was impossible to recognize psoriasis (Ebbel, 1937).

Data about medicine among ancient Hebrews were scarce, mostly preventive in nature, and can be found only in their religious books the Old Testament and the Talmud. In the Leviticus, a short description of a cutaneous disease called zaraath (translated in Greek as 
lepra) was found, which some believed to be leprosy, psoriasis, vitiligo, fungal diseases, or even some other skin condition (Goldman et al., 1966).

The Ayurvedic, religious medicine, developed in India during antiquity. It was based on magic-religious rites, with using of certain plants. Among the medical books from that period the great importance had the Charaka Samitha. In this book and in the Bower manuscript, the disease named Khusta was described briefly. The disease was probably leprosy, although Paul Richter supposed it was psoriasis (Menon \& Haberman, 1969; Richter, 1928).

In the golden age of Greek science, the father of western medicine - Hippocrates (ca. 460- 377 $\mathrm{BC}$ ), separated diseases from divine influences and religious procedures. He used the word psora that meant itch for itchy lesions on the eyelids and genitals. This condition was not psoriasis undoubtedly, though he used tars and climate to treat that disease (Hippocrate, 1839). He also grouped various skin conditions under the term of lopoi, that in Greek mean scale and introduced the word alphos and leukos for some skin diseases with maculae but doubtless not for psoriasis (G. Sticker, 1931).

The first description of psoriasis appear during the Roman Empire in the 1st century AD in the books of A. Cornelius Celsus » De re medica libri octo». The disease was described as impetigo that can appear on the skin of the extremities and nails (the second, the 4th or third type according to different authors). The disease was treated with medicaments containing pitch and sulphur. Interestingly, Celsus did not use the words psoriasis, psora, lepra (Bechet, 1936).

The word psora had been mentioned in the books «Naturalis historia» of the other Roman encyclopedist Pliny, but he did not describe better the disease, for which he recommended the root of cucumber. It is possible that the term alphos also described psoriasis (Celsus, 1989).

Galen (131-201 AD) of Pergamon, physician of some Roman imperators, was the first who used the term psoriasis, but only for an itchy, scaly eruption of the eyelids and scrotum, that was probably seborrheic dermatitis (Galenus, 1830; Plinius, 1969).

In the manuscripts of the greatest physicians of antiquity we found little about psoriasis, probably because they gave little importance to the skin, believing the organ merely a web to hold together the other parts of the body. Recently Karl Holubar wrote minutely about the semantic aspects of the word psoriasis, and stated that no clear clinical description of psoriasis can be found in the works of the ancient writers (Holubar, 1990).

In the pre-Columbian period in America the Maya, the Aztecs, the Incas, and the Nahuas had a kind of medicine in which magic and religious elements were interwoven, but also treated skin diseases with plants. A disease, probably psoriasis, they treated topically and internally with herbs and resins (Obermeyer, 1974).

\subsection{Psoriasis in the middle age}

After the extinction of the Roman Empire by the Goths take place the darkness of the Middle Age, a period of stagnation which negatively affected the development of science (Porter, 1999). The literate men were confined to monastic cloisters and medicine was full of superstition, ignorance and mysticism and gave little attention to skin diseases. Writers 
according to Hebra spent their time in frivolous commentaries of the ancient classic writers, physicians or no, while the cause of the diseases remained unknown (Bechet, 1936). The majority of the people was cured by quacks and barbers often illiterate.

The Arabian physicians perhaps first distinguished psoriasis from other skin diseases already in the VIII century A.D., and it seem they used a kind of psychotherapy in treatment (Shafii \& Shafii, 1979).

In Western the first medical School was founded in Salerno, where Constantine the African translated old medical manuscripts from Greek and Arabic to Latin. By the 13th century most manuscripts had been translated into Latin that became the dominant language of the educated people.

\subsection{Psoriasis in the renaissance}

The Renaissance was a cultural movement that spanned roughly the 14th to the 17th century, beginning in Florence in the Late Middle Ages and later spreading to the rest of Europe. During this time some authors mentioned the diseases psora and lepra in their books. Among these was Johannes Manardi (1462-1536) from Ferrara, who mentioned the disease "psora" in his "Epistolae medicinales", but wrote nothing more about (Manardi,1542).

The most important work on skin disease was written by Hieronymus Mercurialis (15301606), professor of medicine at the universities of Padua, and Bologna. The book was entitled »De morbis cutaneis et omnibus corporis humani excrementis» and based on his lectures transcribed by his student Acardius. For this book Garrison said «the first systematic text book on diseases of the skin". Mercurialis divided the skin diseases, similarly to Galen "a capite ad pedes" in those of the scalp and then of the entire body, both subdividing in change of the color, change in structure and bulks. He described psoriasis under the name of "lepra grecorum" and for other condition used the term "psora" (Mercurialis, 1572).

In 1700, B. Ramazzini (1633-1714) published his original work "De morbis artificum diatriba" in which the diseases caused by the work in certain professions was described, among them also skin conditions. Ramazzini pointed out a lot of new causes of diseases different from the Hippocrates's theory of a dyscrasia of humors (Ramazzini, 1700).

\subsection{Psoriasis in 18th century}

During the 18th century a few surgeons and physicians tried to devote oneself to the study of the skin and its diseases. Among them was Daniel Turner (1667-1740), who firstly started to work as a surgeon, then obtained in America at Yale a honorary degree of doctor medicine. In 1714 he published the book entitled «De morbis cutaneis a treatment of diseases incident to the skin», that went through a few editions and was soon translated in other languages (Turner, 1726). He gave not an accurate description of psoriasis that he called "leprosy of the Greek", while "leprosy of the Arabian" was our leprosy. He was aware that the local application of ointments and drugs transfer them internally.

In the second part of the 18th century the great Swedish naturalist and physician Carl Linnaeus (1707-1787) introduced the binomial terminology and first classified the plants in a 
comprehensible manner. In 1735 he published this in his book »Systema naturae» and later even proposed to classify the human diseases in his «Genera morborum» (Linnaeus, 1763). The same topic, in the same year, one can find in Francois Boissier de Sauvages who in his work "Nosologia methodica" classified diseases in ten classes with about 2400 species (Grmek, 1996). These types of classifications were soon used in the classification of skin diseases.

In 1777 Charles Anne Lorry (1726-1783), who became the physician of Louis XVI and can be considered the first French dermatologist, published in Paris his «Tractatus de morbis cutaneis». The book contained more than 700 pages, in which one can find the first attempt of an etiologic classification of skin diseases as well the interaction between internal organs, especially the gastrointestinal, nerve system and the "skin organ" (organum constitutit). Perhaps he was the first who described the Auspitz sign (Lorry, 1777).

Joseph Jacob von Plenck (1738-1807) a Hungarian excellent surgeon and obstetrician in Vienna and expert in botany compiling a list of about 800 medicinal plants, in 1776 published the little book entitled «Doctrina de morbis cutaneis». In his book the diseases was classified on morphological basis i.e. the elementary lesions of 120 skin diseases in 14 classes, even the entities were often unidentifiable (Plenck, 1776). He gave only marginally attention to psoriasis (seated in the class of squames) and its therapy, and used the old term impetigo for it (from Latin impetus - to attack).

For long time the surgeon treated skin diseases and therefore D. Turner, C. Lorry, and J. Plenck can be considered the protodermatologist (Holubar \& Ferenčić, 2002). Their effort opened the way to the first dermatologist like R.Willan and JL. Alibert.

Two decades after Plenck, the English physician Robert Willan (1757-1812), working at the London Public Dispensary published the Book «On cutaneous disease» in which he developed a simpler, better and usable classification of the skin diseases on the basis of eight elementary lesions (Willan, 1798). He used the term psoriasis for the papulosquamous disease, in the order squamae, together with lepra, pityriasis and ichthyosis and partly differentiated psoriasis from leprosy (psora leprosa and lepra grecorum). He described different forms of psoriasis: guttata, diffusa, gyrata, palmaria, unguium, inveterata. He also noticed that the disease begin on the knees and elbows, attack the scalp and also the finger and toe-nails. During his life he published the skin diseases of the first four orders (Willan, 1809). After his premature death, his work was continued and completed by his disciple and successor Thomas Bateman (1778-1821), who also published some books on the subject paying attention on the treatment.

At the beginning of the XIX century the great French physician Jean Louis Alibert (17681837) worked and taught at the Hospital of St. Louis in Paris, dedicated to skin diseases. He opposed to Willan classification and also attempt to make order and systematize the skin diseases. He followed the ideas to classify diseases in agreement with another botanist B. de Jussieu based on the analogy and divided the skin diseases in 12 classes or groups. He also later (1829) proposed an « arbre des dermatoses» (in English-tree of skin diseases), a rather naive scheme, which made only a greater confusion. Psoriasis classified in the group of dartrous dermatoses together with leprosy (Alibert, 1832).

In this century hospitals or dispensaries were opened only for treatment of skin or venereal diseases giving to the physicians the opportunity to study more cases of skin diseases and psoriasis as well. 
It was Ferdinand von Hebra (1806-1880) who in 1841, working in Vienna at the Allgemeines Krankenhaus definitely divided psoriasis from leprosy (improving the terminology and classification of R. Willan). He was a popular teacher and became the first professor of dermatology of German languages, and more importantly he classified the skin diseases in 12 groups not only on the basis of gross anatomy, but after Karl Rokitansky (1804-1878) used also the microscopic criteria for their classification (Hebra, 1856), introducing general pathology to describe skin diseases. Regard psoriasis treatment he believed in pilulae asiaticae (arsenic) (Bechet, 1936). His successor Moritz Kaposi also continued on this way.

\subsection{Psoriasis in 19th century}

During the 19th century the dermatologists continued to dispute about the classification of skin diseases. Dermatology and also psoriasis grew and develop with the introduction of pathohistological classifications (F. Hebra, Auspitz). Regard psoriasis it is to underline that Alibert noted in 1822 the association of the disease with joint deformities (Alibert, 1818), for which Besnier coined the name arthritis psoriatica. The association was later detailed by Charles BOURDILLON (Bourdillon,1888), while Erasmus Wilson described the association of psoriasis with gout and rheumatic diseases.

The description of the varieties of psoriasis followed: psoriasis pustulosa generalisata in 1910 by Leo von Zumbusch (1884-1940) (von Zumbusch,1910), and later the of psoriasis palmo-plantaris by Barber-Königsbeck.

Some authors described signs that helped the diagnosis of this disease. Heinrich Köbner (1838-1904), professor of dermatology in Breslau, described the isomorphous effect of irritation or Köbner phenomenon in 1872, i.e. appearence of a psoriatic lesion at the site of a physical or other injury (Köbner,1877). Later this phenomenon was used experimentally to study the early changes that appear in the disease.

Heinrich Auspitz (1835-1886), a Hebra pupil, described the appearance of papillary bleeding after the removal of the scales from a psoriatic lesion (Auspitz sign or bloody dew phenomenon), even this sign had been before noted by D.Turner, R.Willan and F.Hebra. Auspitz was interested in dermatopathology, and introduced a few pathohistological terms such parakeratosis and acanthoma typical for psoriasis (Pusey, 1933). In 1879 Duncan and Bulckley described the "pellicole decolable". Hard debates followed about the possibility of psoriatic manifestation on mucous membranes particularly on the oral cavity.

At the end of the 19th century psoriatic micro morphology was described by Hebra, Unna, and William Munro who described the microabscess (micropustule), i.e. the accumulation of neutrophils in the stratum corneum.

\subsection{Psoriasis in 20th century}

During the first part of the 20th century the Woronoff ring was described around the psoriatic plaque (1926) especially after treatment with antrarobin (Woronoff , 1926; Kogoj , 1927)

The spongiform pustule in pustular psoriasis was described 1927. by Franjo Kogoj (18941981) who working in Zagreb and later better defined by Mladen Rupec through a ultramicroscopic study (Kogoj,1927; Rupec, 1970). 
In the second part of the 20th century it was demonstrated that the psoriatic epidermis contains 25 times more mitoses per unit than the epidermis from healthy persons. van Scott and Ekel demonstrated that the keratinocytes of psoriatic patients have a significant shortening of their cell cycle from about $311 \mathrm{~h}$ in normal person to $36 \mathrm{~h}$; (van Scott, 1963) and the turnover time of the epidermis is markedly shortened, from 27 days to 4 days ( Weinstein, 1968).

In $20^{\text {th }}$ century many authors studied the genetic alteration and today there is undisputed evidence that the disease is multifactorial i.e. caused by multiple genes. Many of these " susceptible " genes are mapped on different chromosomes (PSOR1-PSOR 10). The disease is triggered also by different environmental factors (Sanchez, 2007; Bowcock \& Barker, 2003).

The association with the HLA molecules was described especially for type 1 of psoriasis, that is frequently inherited, has a more severe course and develops early, while in type 2 the disease develop later and is rarely inherited (Henseler \& Christopher, 1985).

Last decades numerous immunological researches accumulate evidence of presence of alteration of the innate and adaptive immune response in psoriatic patients. Investigations evidentiated an accumulation of activated lymphocytes, mostly CD4 in the dermis and CD8 in the epidermis. This imply a primary disregulation in of the immune system and permitted a better understanding and new insight in the pathogenesis as well new possibilities in the management of psoriasis (Krueger, 2002). Psychological stress also can influence the course of the disease.

\section{The treatment of psoriasis through history}

D. Turner describe very realistically in his book cases of psoriasis treated with inunctions of a ointment containing ammoniated mercury (Hydrargyri amidochlorati) or with a broth of boiled vipers (Turner, 1726). Although very interesting, such details of the treatment are beyond the scope of our article. As the diagnosis of psoriasis before the 19th century was rather debatable, and the treatment usually problematic and ingenuous, we will expose the treatment of psoriasis from the beginning of the XIX century. The treatment of course was topical and/or internal, but for a long period of time the physicians gave more attention to the internal, believing that the external application of drugs on the skin can drive inward the lesions and so cause " metastases» to the internal organs. It was Hebra who asserted this is only speculation.

\subsection{The treatment of psoriasis in $19^{\text {th }}$ century}

One of the first used internally medicaments for psoriasis treatment was arsenic. In 1806 Thomas Girdlestone was the first who used potassium arsenite as solutio Fowleri, following a moderate use, usually 6 drops 3 times a day (Girdlestone, 1806). This solution was introduced into medicine in 1780 by the English physician and pharmacist Fowler (Fowler, 1786). The drug was easily absorbed and then deposited in various organs, especially in the skin and hair, actihg through inhibiting some enzymes. Years after, F. Hebra, M.Kaposi and E. Wilson also recommended solutio Fowleri (before a meal in water or a bland tea) and pilulae asiaticae (consisting of arsenic, black pepper, acacia and water) in the treatment of psoriasis (Bechet, 1936). It seems that arsenic compounds improved mostly psoriasis guttata, sometimes other forms of the disease. 
In 1869 Lipp introduced the subcutaneous injections of arsenous acid (Piffard, 1881).

The protracted use of arsenic in a chronic disease like psoriasis with time led to its accumulation and toxicity. On the skin, liver, and other organs pigmentations, keratoses and malignant tumors appeared. In spite of this horrible adverse reactions arsenic remained in use to the middle of the XX century and the introduction of corticosteroids in the therapy of psoriasis (Gruber et al., 2004).

Mercury was used for centuries in the treatment of syphilis and skin diseases. Mercury ointments was used also by Bateman and by other physicians during the XIX century. According to Henry Pfiffard (1842-1910) the internal use of calomel was also extolled by Biett, Rayer and other physicians (Piffard, 1881) Brault in 1895 used organic mercury compound injections in the treatment of arthritis psoriatica (Brault, 1895). Still in $1972 \mathrm{~W}$. Jadassohn and F. Kogoj recommended a mercury ointment for psoriasis capillitii (Jadassohn \& Kogoj, 1972).

Many disease as well as psoriasis were considered infectious diseases and an antibacterial treatment introduced (iodine, phenol, acetic acid). Among other drugs used internally for psoriasis treatmen were diuretics (petroselinum apium, foliae uvae ursi, digitalis, tinctura cantharides), with little benefit.

The local or internal (intramuscular) use of sulphur and salicylic acid in treatment of skin disease in general is very old. Hebra and Kaposi used sulphur and salicylic acid in various ointments, obtaining the removal of the scales (Hebra, 1845).

For centuries in India Chrysarobin was used in the treatment of dermatomycoses and perhaps psoriasis i.e. long before the English physician Balmanno Squire in 1876 wrote about its use for psoriasis (Squire, 1878). The drug was present in the Goa (or Bahia) powder, obtained from the center of the trunk of the tree Andira Araroba (Vataireopis araroba), which grows in some parts of Brasil (Swanbeck, 1992). Chrysarobin is an antranone that easily oxidizes and its concentration in the powder was very variable. This drug was used in the form of 1-5\% ointment and when applied on skin it cause itching and colored the skin and linen. These effects prevented a larger use of this drug at home. The drug was effective, but expensive and toxic.

\subsection{The treatment of psoriasis in the $20^{\text {th }}$ century}

Around the change of the century the development of chemistry and technology especially in Germany and England favored the synthesis of new drugs for disease treatment. The chemist Galewsky synthesized dithranol (cignolin) in 1916., which permitted easier to cure psoriasis. The first to use it were the Galewsky brother and PC Unna (Galewsky, 1916). It was applied as ointment or paste $(0.1 \%)$ or later as a stick for short contact therapy of psoriasis.

Already Hippocrates used tars in the treatment of skin disease (mostly pine tar). Tars were often used during the last two centuries. Little improvement in psoriasis was obtained with wood tars (of pine, birch, juniper, pix betulina) containing acetic acid, phenol, carbonic acid. They were incorporated in ointments, paste, oils and applied directly on the skin, or used for baths (Leigheb, 1958). Because of their acidic character tars were irritative and also stained brown or purple the skin and clothes. Bituminous tars such as ichthyol were also used. 
After the introduction of coal tar obtained from distillation of coal in the manufacture of illuminating gas, greater improvement in psoriasis treatment was observed. This substance had an antiproliferative and antimflammatory action but also had an unpleasant odor and irritating potential. It was also phototoxic under UVA and visible rays.

In 1925 Goeckerman (1884-1954) used coal tar in conjunction with ultraviolet light irradiation (Goeckerman, 1925). Because of possible carcinogenic action this method is today only used in the treatment of psoriasis palmoplantaris. Ingram developed a treatment of psoriasis based on coal tar and UVB irradiation.

For centuries diet was used in the treatment of different diseases. Naturally there were also numerous attempts to treat psoriasis with diets like low fat( Grütz and Bürger), high fat, vegetarian (Brocq, Buckley), low or high contains of kalium (Weirich, 1960). Probably some effect, if it was, can be linked to a diminished intake of calories that can lower the epidermal proliferation as the cells for this need energy.

The benefical effect of sun on skin diseases was known among the old civilizations, and heliomarinotherapy is used also in our time. Artificial ultraviolet radiation was introduced in medicine by Finsen at the beginning of XX century. Alderson, in the twenties, reported an improvement with UVR in psoriasis (Alderson, 1923). In the last decennia lamps were developed with wavebands between 300 and $320 \mathrm{~nm}$, with narrow spectrum around $311 \mathrm{~nm}$ and PUVA therapy. In 1973 Tronnier and Schule first found a good improvement of psoriasis after the topical use of psoralens and UVA (Tronnier / Schule, 1973). The next year JA Parish at Harvard used oral 8-methoxy- psoralens and UVA irradiation, and soon later H. Hönigsmannn (Parrish et al., 1974; Wolff et al., 1975) Few years later, 5- methoxypsoralen in photochemotherapy was introduced in Vienna (1979). This treatment was highly effective and gave long lasting remissions.

At the middle of the 20th century corticosteroids were introduced into medicine. The first treatment of psoriasis with topical corticosteroids made M.B. Sulzberger and V.Witten in 1952., but the local application of cortisone and hydrocortisone was without effects on psoriasis (Sulzberger, 1952).

Changing the steroid molecule with fluoridation permitted to obtain more potent steroids like fluocinolone acetonide, betamethasone valerate and clobetasol propionate. These drugs were effective in clearing most cases of psoriasis. Their efficacy can be enhanced with occlusive dressing or using combination with salicylic acid, tars and other. The drawbacks of this therapy are atrophy of the skin, telangiectasias, suppression of the hypothalamuspituitary-adrenal axis and tachyphylaxis.

Among other drugs employed in the treatment of psoriasis are the cytostatics and antimetabolits. Particular mention deserve folate inhibitors like aminopterin and methotrexate, introduced in the 1950s, which in disabling cases of psoriasis and psoriatic arthritis can give a satisfactory response (Gubner, 1951; Edmundson \& Guy, 1958). In recent years the internal use of Cyclosporine, an immunosuppressive drug, inhibiting $\mathrm{T}$ cell activation, showed favorable results in the treatment of the disease, but a problem represents its nephrotoxicity (Mueller \& Herrmann, 1979).

In the "70s the Retinoids, analogs of Vitamin A, were introduced in treatment of psoriasis, especially of erythrodermic and pustular form. The introduction of systemic retinoids 
represented a great step forward for the patients. First was synthesized isotretinoin and used for psoriasis in 1972, later were introduced etretinate and acitretin that showed a better efficacy and lower toxicity. (Orfanos \& Runne, 1976; Kingston et al., 1987). They act through the nuclear receptors RAR and RXR and on the expression of genes important for the proliferation and differentiation of keratinocytes. Retinoids can be used in combination with PUVA. It is important to avoid their use during pregnancy being teratogenic (Lammer et al., 1985).

Last decades analogs of vitamin D3 (calcipotriol, tocalcitol) showed to slowing the epidermopoiesis and stimulate the differentiation of keratinocytes in cultures and were introduced in the topical treatment of psoriasis (Smith et al., 1986).

\subsection{The future: The 21th century}

Decades of research evidenced he importance of the immune mechanisms in the insurgence of psoriasis. The introduction of biological agents in he therapy of psoriasis and further elucidation in the pathogenesis of the disease (Tutrone et al., 2004) permitted us to believe to bolster in the future use of drugs that act on specific receptors (IL-2), cytokines, chemokines or on some other molecules of the lymphocytes (Mrowietz, 2003). Monoclonal antibody humanized or recombinant and fusion proteins will find employment in the treatment of psoriasis as they can act on molecules on the surface of lymphocytes such CD4, $\mathrm{CD} 2$, or on molecules present on the surface of antigen presenting cells. Other may block some of the proimflammatory cytokines like tumor necrosis factor a or perhaps interleukins that deviate the TH1 to TH2 immune response. Monitoring for infections, autoimmune reactions are necessary.

Also, the discovery done by O'Daly opens a new door for understanding and treatment of psoriasis. While injecting volunteers with vaccine for prevention of leishmaniasis, clinical remission of psoriasis was observed. The results confirmed in a controlled study demonstrated favorable benefit/risk profile and merits further development for the treatment of psoriasis ( $\mathrm{O}^{\prime}$ Daly et al.,2008). There are factors in Leishmania species which induce remission of psoriasis by stimulating lymphocytes (O'Daly et al; 2010). Furthermore, Antigens from Leishmania amastigotes inducing clinical remission of psoriatic arthritis (O’Daly et al.,2011).

The new local, systemic, photochemotherapy and psychological treatments can be a substantial aid in the management of the disease, and will permit to improve the quality of life in psoriatic patients. Psoriasis vulgaris and other forms burden are not only related to alteration of the skin, but frequently can involve also to the joints, cardiovascular problems, and a metabolic syndrome. This historical review of psoriasis and its treatment from the Ancient times until today, alike the study of the skin and its diseases, illustrate efficiently the complexity of its etiology, the dilemmas of language barriers, chaos of the confounding nomenclature that endurated in this fields, and this is well illustrated by the innumerable books and articles written in the last centuries about this enigmatic disease.

Psoriasis as a common disease has a significant socio-economic impact on the individual and on the society.Today dermatology and so fairly psoriasis need the support of other scientific disciplines like molecular medicine, genetics, immunology, and pharmacogenetics. 


\section{References}

Alibert, JL. (1818). Precis theorique et pratique sur les maladies de la peau.Vol 2, Caille et Ravier, Paris.

Alibert, JL. (1832). Monographie des dermatoses. Precis theorique et pratique des maladies de la peau. Daynac, Paris.

Alderson, HE. (1923). Heliotherapy for psoriasis. Arch Dermatol, 8, , pp 79-80.

Bechet, PE. (1936). Psoriasis. A brief historical review, Arch Derm Syph 33,No2, pp327-334.

Bowcock, AM., \& Barker, JN. (2003). Genetics of psoriasis: the potential impact on new therapies, J Am Acad Dermatol 49 (suppl 2):s51-56.

Bourdillon,C. (1888). Psoriasis et arthropathies. These, Paris.

Brault, J. (1895). Deux cas de psoriasis traite par les injections mercurielles. Bull Soc Franc Dermatol, pp 332.

Celsus, CA. (1989) De Medicina, Transl by Spencer WG, Book V, 17. Harward University Press, Cambrige, pp168-173.

Ebbel, B. (1937).The papirus Ebers, Levinn-Munksgaard, Copenhagen.

Edmundson, WF., \& Guy BW. ( 1958) Treatment of psoriasis with folic acid antagonists. Arch Dermatol,78, No2,pp 200-203.

Fowler, T.(1786) Medical reports on the effects of arsenic in the cure of agues remitting fevers and periodical head aches. London Med J,7, pp192-205.

Galewsky, E. (1916). Über Cignolin, ein Ersatzpräparat des Chrysarobins. Derm Wschr,62, pp 113-115.

Galenus, C. (1830). Opera omnia. C. Kuhn ed, Cnobloch, Lipsia, pp 449.

Girdlestone, T. (1806). Observation the effect of dr. Fowler's mineral solution in lepra et either disease. Med Phys J,15 pp 297.

Goldman, L., Moraites, RS., \& Kitzmiller, K. (1966) White spots in Biblical times. Arch Dermatol; 93, No 6, pp748-753.

Goeckerman, WH.(1925) Treatment of psoriasis. Northwest Med ,24, pp229.

Gubner, R.(1951) Effect of Aminopterin on epithelial tissue. Arch Derm Syph, 64, No6, pp 688-699.

Grmek, M.(1996). Il concetto di malattia. In :M. Grmek,ed, Storia del pensiero medico occidentale. 2 Dal rinascimento all' inizio dell' Ottocento, Laterza, Bari, pp279.

Gruber, F., Kaštelan, M.,\& Brajac, I.( 2004). Psoriasis treatment - Yesterday, today, and tomorrow. Acta Dermatovenerol Croat,12, No2, pp30-34.

Hebra, F. (1856-1876) Atlas der Hautkrankheiten. Vol I-X, Wien.

Hebra, F. (1845) Versuch einer auf pathologische Anatomie gegründeten Einteilung der Hautkrankheiten. Zeitschr der K uK Gesellschaft der Aertze in Wien:2, pp211-231.

Henseler, T.,\& Christopher, E. (1985) Psoriasis of early and late onset: characterization of two types of psoriasis vulgaris . J Am Acad Dermatol,13,No3, pp450- 456.

Herodotus.(1989) Le storie Vol 1-2.( Greek-Ital. transl.)p84, Garzanti, Milano.

Hippocrate.( 1839-1861). Ouvres completes. Transl. et ed. E. Littre, Bailliere et fils, Paris vol I-X.

Holubar, K., \& Ferenčić -Fatović, S. (2002).The roots of international dermatology: seven useful tables on the first dermatological personalities and achievements. European Society for history of dermatology and venereology, Paris,pp 1-7.

Holubar, K. (1990).Psoriasis 100 years ago. Dermatologica,180,No1, pp1-4. 
Jadassohn, W.,\& Kogoj, F.(1972). Bemerkungen zur psoriasistherapie. Proceeding VII Congres dermatovenerologists Jugoslavije, Opatija - Rijeka, 1972, pp 65.

Kogoj, F.(1927).Un cas de maladie de Hallopeau. Acta Dermatovenereol,8, No1,pp1

Köbner, H.(1877) Zur Aetiologie der Psoriasis. Wschr Derm, 4,pp203-20.

Krueger, JG. (2002)The immunologic basisfor the treatment of psoiasis with new biologic agents. J Am Acad Dermatol,46, No1, pp1-23.

Kingston,T., Matt, L.,\& Lowe, N.(1987). Etretin therapy for severe psoriasis. Arch Dermatol, 123,No1 pp55-58.

Lammer, EJ, Chen, DT,Hoar, RM ret al.(1985). Retinoic acid embriopathy $N E J M$, 313,No14, pp 837-841.

Lorry, C. (1777).Tractatus de morbis cutaneis. G. Cavelier, Paris.

Leigheb, V.(1958). Il valore pratico attuale della terapia esterna medicamentosa delle malattie cutanee. Minerva Dermatol, vol 33(suppl 1), pp81-82.

Linnaeus, C. (1763). Genera morborum. Uppsala.

Menon, IA., \& Haberman, HF.(1969) Dermatological writings of Ancient India. Med Hist,13, pp387- 392.

Manardi, J.(1542) Epistolae medicinales, Schaeffer, Venetii.

Mercurialis, H.(1572). De morbis cutaneis et omnibus corporis humani excrementis. P.A. Meietos, Venetiis

Mueller, W.,\& Herrmann, B. (1979) Ciclosporin A for psoriasis. N Engl J Med 301, No10,pp 555.

Mrowietz, U.(2003). Therapie der Psoriasis mit Biologicals. Hautarzt, 54, No3, pp 224-229.

O'Daly, JA., Lezama, R., \& Rodriguez, PJ. et al. (2008). Antigens from Leishmania amastigotes induced clinical remission of psoriasis. Arch Dermatol Res,No 301, pp 113 .

O'Daly, JA., Lezama, R., \& Gleason, J. (2009) Isolation of Leishmania amastigote protein fractions which induced lymphocyte stimulation and remission of psoriasis. Arch Dermatol Res,No 301, pp 411-27.

O'Daly, JA., Gleason, J., Lezama, R., et al. (2011). Antigens from Leishmania amastigotes inducing clinical remission of psoriatic arthritis. Arch Dermatol Res,No 303, pp 399415.

Obermeyer, ME.(1974) Mexican dermatology of the Pre- Columbian period. Intern J. Dermatol 3, pp293-299

Orfanos, CE, \& Runne, U. (1976) Systemic use of a new retinoid with and without local dithranol treatment in generalized psoriasis. Br J Dermatol, 95, No1, pp101-103.

Parrish, JA., Fitzpatrick,TB., Tannenbaum, L.,\& Pathak MA.(1974). Photochemotherapyof psoriasis with oral methoxsalen and long wave ultraviolet light. $N$ Engl J Med, 291,No23,pp1207-211.

Piffard, HG.(1881). A treatise on the materia medica and therapeutics of the skin. W. Wood, New York.

Plinius, C. (1969).Naturalis historia. Harward University Press, Cambrige, XXIII,3.

Plenck, J J. (1776). Doctrina de morbis cutaneis, R. Graeffer, Wien.

Porter, R. (1999). The greatest benefit to mankind. Harper Collins, . UK, pp106

Pusey, WA. (1933). History of dermatology. CC Thomas, Springfield, pp33.

Radbill, SX.(1975) Pediatric dermatology in Antiquity (part1). Intern J Dermatol ,14, No 5, pp 363-368. 
Richter, P.(1928) Geschichte der Dermatologie. In J Jadassohn ed: Handbuch der Haut u. GeschlechtsKrankheiten, Vol XIV/2, J Springer, Berlin pp1-240.

Ramazzini, B.(1700). De morbis artificium diatriba. Modena 1700

Rupec, M.(1970) Zur Ultrastruktur der spongiform Pustel. Arch Klin Exp Derm, 239,pp30

van Scott, EJ.,\& Ekel, TM.(1973) Kinetics of hyperplasia in psoriasis. Arch Dermatol ,88, No4,pp 373- 381.

Sanchez, F. (2007).The genetic of psoriasis susceptibility. G It Dermat Venereol,142, No5, pp 489-501.

Shafii, M., \& Shafii, SL. (1979) Exploratory psychotherapy in the treatment of psoriasis twelve hundred years ago. Arch Gen Psychiatry, 36,pp1242-1245.

Smith, EL.,Walworth, ND., \& Holick, HK.(1986). Effect of 1 alpha -25 dihydroxy vitamin D3 on the morphology and biochemical differentiation of cultured human epidermal keratinocytes grown in serum free. J Invest Dermatol , 86, No6, pp709-714.

Squire, B.(1878). On the treatment of psoriasis by an ointment of chrysophanic acid. Churchill, London, pp8.

Sticker, G.(1931) Entwurf einer Geschichte der ansteckenden Geschlechtskrankheiten. In J. Jadassohn ed: Handbuch der Haut u. GeschlechtsKrankheiten,Vol XXIII, J Springer, Berlin.264- 603

Sulzberger, M.B., \& Witten, VH.(1952) The effect of topically applied compound F in selected dermatoses. J Invest Dermatol, 19, No2,pp101-102.

Swanbeck, G.(1992). Der Baum, aus welchem Chrysarobin gewonnen wurde. Hautarzt, 43, No 6, pp 388-389.

Tronnier, H., \& Schule, N. (1973).Zur dermatologischen Therapie von Dermatosen mit Langwelligen UV nach Photosensibilisirung der Haut mit Methoxsalen, erste Ergebnisse bei Psoriasis vulgaris. Zeitschr Haut Geschlkr, 48,pp385-393.

Smith, EL.,Walworth, ND., \& Holick, HK.(1986). Effect of 1 alpha -25 dihydroxy vitamin D3 on the morphology and biochemical differentiation of cultured human epidermal keratinocytes grown in serum free. J Invest Dermatol , 86, No6, pp709-714.

Tutrone, WD., Saini, R., \& Weinberg, JM.(2004) Biological therapy for psoriasis: An overview of infliximab, etanercept, efalizumab and alefacept. Drugs, 7, pp 45-49.

Turner, D. (1726). Disease incident to the skin. III ed. Bonurike, London, pp45.

Willan, R.(1798). On cutaneous diseases: Johnsen, London.

Willan, R.(1809). On cutaneous diseases.Vol 1, Johnson St. Pauls Church Yard, London.

von Zumbusch, L.(1910). Psoriasis und pustuloses Exanthem. Arch Dermatol syphilol 1910:99:335.

Weinstein, GD. et al,(1968) Abnormal cell proliferation in psoriasis. J Invest Dermatol, 50,No 3, pp254.

Weirich, E G.( 1960) Die systemisce Therapie der Psoriasis. Hautarzt, 11, No5,pp193-201.

Wolff, K., Königsmann, H., Gschnait, F et al.(1975). Photochemotherapie bei Psoriasis Klinische Erfahrungen bei 153 Patienten. Dtsch Med Wschr, 100, pp 2471-2477.

Woronoff, DL.(1926).Die peripherenVeranderungen der Haut um die Effloreszenzen der Psoriasis vulgaris und Syphilis corymbosa. Derm Wschr, 82, pp249-258. 


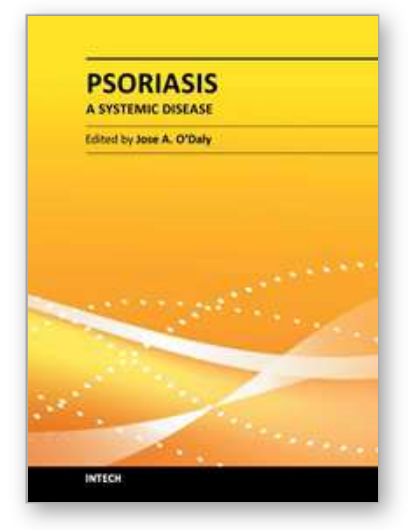

\author{
Psoriasis - A Systemic Disease \\ Edited by Dr. Jose O' Daly
}

ISBN 978-953-51-0281-6

Hard cover, 216 pages

Publisher InTech

Published online 16, March, 2012

Published in print edition March, 2012

The purpose of this book is to present a comprehensive analysis of Psoriasis, a disease that affects approximately $2-3 \%$ of humanity in all countries. Psoriasis existence is surveyed since the clay tablets of Assyrians and Babylonians 3.000-5.000 years ago, thru the middle ages, the renaissance, XIX and XX centuries.

\title{
How to reference
}

In order to correctly reference this scholarly work, feel free to copy and paste the following:

Ines Brajac and Franjo Gruber (2012). History of Psoriasis, Psoriasis - A Systemic Disease, Dr. Jose O' Daly (Ed.), ISBN: 978-953-51-0281-6, InTech, Available from: http://www.intechopen.com/books/psoriasis-asystemic-disease/psoriasis-history-definition-and-treatment-through-centuries

\section{INTECH}

open science | open minds

\section{InTech Europe}

University Campus STeP Ri

Slavka Krautzeka 83/A

51000 Rijeka, Croatia

Phone: +385 (51) 770447

Fax: +385 (51) 686166

www.intechopen.com

\section{InTech China}

Unit 405, Office Block, Hotel Equatorial Shanghai

No.65, Yan An Road (West), Shanghai, 200040, China

中国上海市延安西路65号上海国际贵都大饭店办公楼405单元

Phone: +86-21-62489820

Fax: +86-21-62489821 
(C) 2012 The Author(s). Licensee IntechOpen. This is an open access article distributed under the terms of the Creative Commons Attribution 3.0 License, which permits unrestricted use, distribution, and reproduction in any medium, provided the original work is properly cited. 